\title{
INTRASPECIFIC VARIATION ON EARLY GROWTH OF Neolamarckia cadamba MIQ. IN PROVENANCE-PROGENY TESTS IN WEST JAVA PROVINCE, INDONESIA
}

\author{
DEDE J. SUD RAJAT ${ }^{1 *}$, NURHASY BI $^{1}$, ISKANDAR Z. SIREGAR ${ }^{2}, \mathrm{ULFAH} \mathrm{J.} \mathrm{SIREGAR}^{2,3}$, \\ IRDIKA MANSUR ${ }^{2,3}$ and NURUL KHUMAIDA ${ }^{4}$ \\ ${ }^{1}$ Foreet TreeSeed Tedndogy Reserch Institte, Bogor 16143, Indonesia \\ ${ }^{2}$ Department of Silvialture, Faailty of Foretry, Insitit Petanian Bogr, Bogr 16680, Indonesia \\ ${ }^{3}$ SEAMEO-BIOTROP, Bogr 16134, Indonesia \\ ${ }^{4}$ Department of Agronomyand Hortiailture, Faailty of Agiailture, Institut Petanian Bogr, Bogr 16680, Indonesia
}

Received 21 October 2014/ Accepted 2 May 2016

\begin{abstract}
ABST RACT
Genetic parameters on early growth of Nedamarkiacadamba, an indigenous species with potential as a source of wood timber, were estimated in open-pollinated provenance-progeny tests at two sites in West Java Province, Indonesia. The experiment was conducted using randomized complete block design with 12 provenances, 105 families and 5 replications of 4-tree row plots. Total height and root collar diameter were measured at the age of 18 months growth. Significant differences among the provenances and families within provenances were observed for height and collar diameter at all sites, except for the collar diameter of among provenances at Parungpanjang site. In general, Garut (G SJ) provenance performed better growth at the two sites than Kualakencana (K KP) and Nusa K ambangan (NKJ) provenances. The evaluation of component of variance at the two sites showed that the provenance effects (ranging from 0.5 to $1.7 \%$ ) contributed more to total variance than family within provenance effects (ranging from 0.4 to $0.6 \%$ ). G enetic correlations between height and collar diameter were weak to moderate. Heritability was low for all traits at Limbangan, while at Parungpanjang, the heritability was moderate. Estimation of genetic gain for height and diameter by proportional selected family 0.30 was 0.13 and 0.18 for Limbangan and 0.31 and 0.16 for Parungpanjang. Heritability measurement should be sustained to reach stable value. Stable heritability combined with selection of family and selection within family will improve genetic gain.
\end{abstract}

Keywords: Genetic correlation, genetic parameter, heritability, Nedamardkia cadamba, progeny, provenance, selection

\section{INTRODUCTION}

Nedamardkia cadamba (Roxb.) Miq. commonly known as white jabon is a native fast growing tree species playing an important role in both commercial and traditional farming systems in several sites in Indonesia (K risnawati $\notin$ al. 2011; $\mathrm{K}$ allio $\mathrm{eal}$. 2011). This species produces timber for pulp and light construction (Soerianegara \& Lemmens 1993). Various parts of the plant also have many bioactive substances, such as antioxidant, hypoglycemic substance, hypolipidemic substance, antibacterial substance, antimicrobial substance, etc. (Acharyya \& al. 2011; Xu \& al. 2011; Mishra \& Siddique 2011).

\footnotetext{
*Corresponding author : djsudrajat@yahoo.com
}

N. cadanba has a very extensive natural distribution extending from India, Nepal, Burma, Sri Lanka and Malaysia across Indonesia, Philippines and Papua New G uinea (Lamprecht 1989). In Indonesia, white jabon is distributed almost across the entire country (Soerianegara \& Lemmens 1993). Evolutionary theory predicts that species with large population sizes, broad geographic ranges and varying climate condition will have large inter and intraspecific variation (Rawat \& Bakshi 2011). Population within plant species with wider geographic ranges has higher allozyme variation and the widely distributed species have more overall allozyme variation (Hamrick \& Godt 1989). Some studies showed that genetic variation of $\mathrm{N}$. cadamba ha been detected among provenances for quantitative 
seed and seedling morpho-physiological parameters (Sudrajat 2016), as well as among natural populations to AFLP loci (Sudrajat \& al. 2015). Given its wide ecological amplitude and a large amount of genetic variation, N. cadambais a promising species for tree improvement program to increase its productivity and quality.

Tree improvement program of $\mathrm{N}$. cadamba is not yet running well, so that large cultivation activities of this species is not yet supported by high quality seed. The main seed sources for all kinds of plantation activities are from unknown origin, which are collected from unimproved seed sources. However, the initiation of the tree improvement program of $\mathrm{N}$. cadamba is very important as a basic for high qualified seed procurement. The success of tree improvement efforts depends upon many factors including genetic variation, heritability of desired parameters and potential gains derived (N ebgen \& Lowe 1982; Borralho 2001), so it is very important to use the genetic material from wide natural distribution of the species to establish a breeding population. In Indonesia, establishment of breeding population with open pollinated progenies of plus trees is widely applied as the first step towards tree improvement for fast growing species (Hashimoto \&al. 1996; Soeseno 1988). It might be the most reasonable and practical way to meet an immediate demand for genetically improved seed to be used in reforestation programs in Indonesia. Traditionally, forest genetic tests have been conducted sequentially with successive species, provenance and progeny trials. In practice, however, there is strong economic pressure to reduce the testing interval between these stages in a traditional tree improvement program. The use of combined provenance-progeny test has been advocated to reduce the testing interval between provenance and progeny stages (Zheng $\&$ al. 1994; Sebbenn eal. 2003; Finkeldey 2005). It may be extended to combine provenance testing, progeny testing, seed production and ex situ conservation of N. cadambain a single trial.

The study investigated intraspecific variation for early growth parameters in 105 families from 12 N. cadamba provenances originated from seven Indonesian islands. The objectives of this research were: i) to examine the distribution of genetic variation among and within provenances and families within provenances and ii) to determine the extent of genetic control for growth parameters in the form of provenanceprogeny test at two different locations in West Java Province, Indonesia.

\section{MATERIALS AND METHODS}

Open-pollinated seeds of 105 families of $\mathrm{N}$. cadanba were collected from 12 natural populations distributed in Sumatera, Java, Nusa K ambangan, Kalimantan/ Borneo, Celebes, Sumbawa and Papua (Table 1, Fig. 1) from March to July 2012. The sampled trees were phenotypically average or above average with respect to stem diameter (diameter at breast height/ D BH) and total height compared with surrounding trees in the population. The distance among mother trees within population was kept at a minimum of $100 \mathrm{~m}$ to minimize relation between seed lots. Seeds were collected by climbing the tree samples. Every seed lot was separated for each sample tree and information about location and number of samples was noted at every seed lot. The information was kept until the seed reached nursery stage to establish the provenance-progeny trials.

Seeds were sown in plastic pot filled with media consisted of sand, compost and charcoal (5:3:1, by volume). Prior to sowing, the potting mixture was treated with $0.2 \%$ a fungicide to avoid any chances of fungus infection attacking newly germinated seedlings. Pots were watersprayed with fine sprayer to keep them wet and were maintained in greenhouse. Young four-leaf seedlings were transplanted on polythene bags (10 $\mathrm{cm}$ in diameter and $15 \mathrm{~cm}$ in height), containing media consisted of top soil, sand and compost in a ratio of 2:1:1 (volume) and were set up in nursery. Seedlings were grown at 50\% light intensity using shade net for 3 months. One month afterwards the seedlings were exposed at open area for hardening off. Seedlings were irrigated based on the operational regime for the nursery. Forty vigorous and healthy seedlings were selected from each family to be planted at two trial sites.

The experiment was set up in two sites in West Java Province, i.e. site I in Limbangan, Garut $\left(07^{\circ} 02^{\prime} 23^{\prime \prime}\right.$ S, $108^{\circ} 00^{\prime} 43^{\prime \prime}$ E, $520 \mathrm{~m}$ altitude) and site II in Parungpanjang, Bogor $\left(06^{\circ} 20^{\prime} 42^{\prime \prime} \mathrm{S}, 106^{\circ} 06^{\prime} 15^{\prime \prime} \mathrm{E}, 52 \mathrm{~m}\right.$ altitude). 
BIOTROPIA Vol. 23 No. 1, 2016

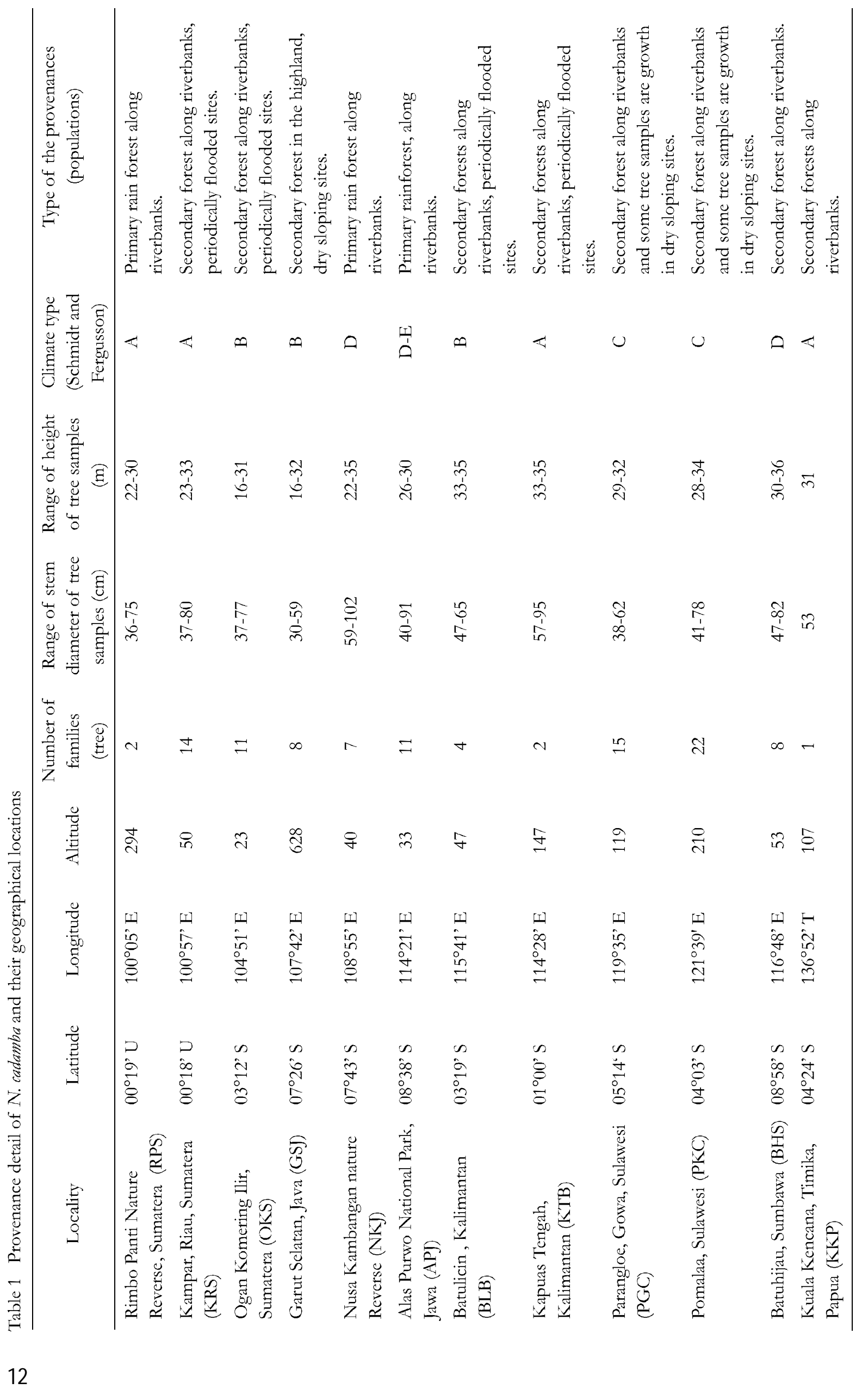




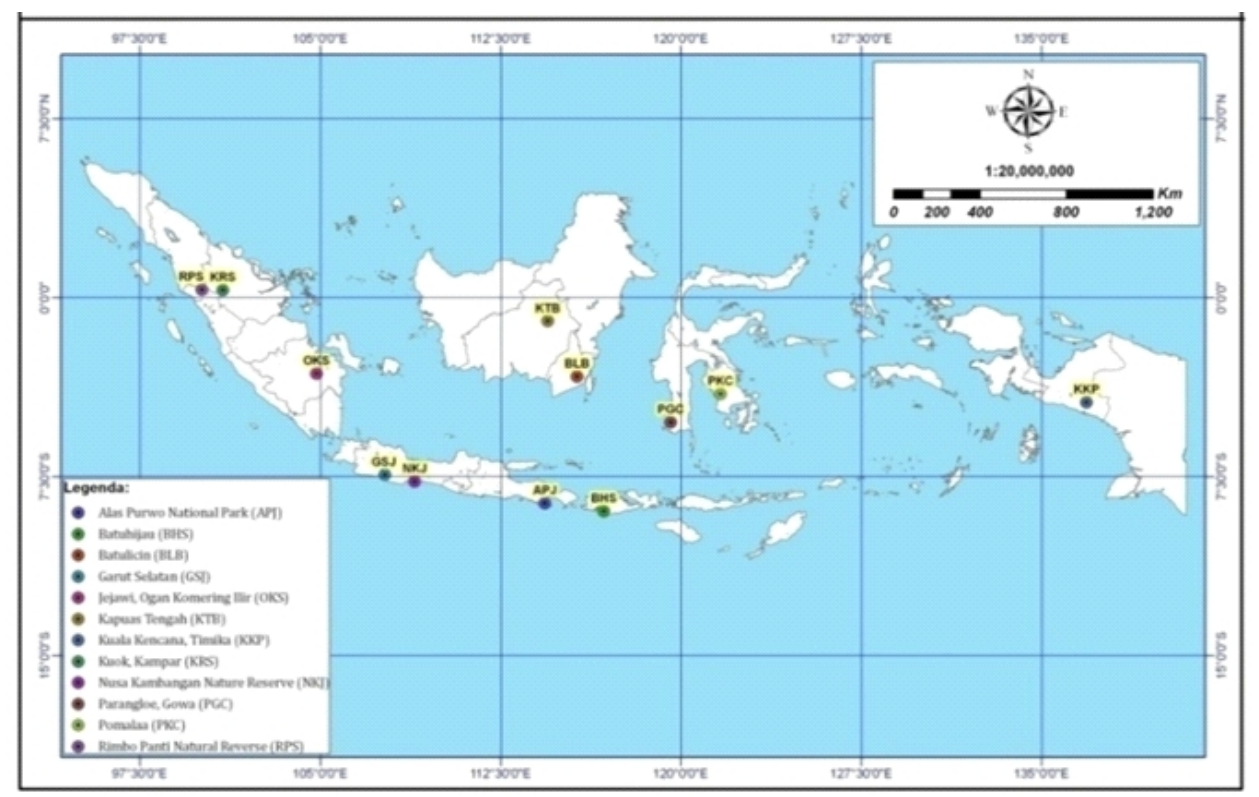

Figure $1 \mathrm{G}$ eographic distribution of 12 populations was tested

Average annual rainfall and temperature were $2,580 \mathrm{~mm}$ and $27^{\circ} \mathrm{C}$ at site I, respectively and $2,440 \mathrm{~mm}$ and $28^{\circ} \mathrm{C}$ at site II, respectively. Soil at site I and site II had low level of N, P, K and Corganic with $\mathrm{pH}$ of 5.1 and 4.2 , respectively. Site I was an open private land with slope ranged from 5 to $15 \%$, having high incidence of domestic animal and was planted with irregular agricultural crops in several parts of area. Site II was an even area within state forest land covered with dense weed, that grew rapidly even after cleaning. The locations were selected based on several reasons. Limbangan was selected to represent medium to high level of elevated land where many N. cadamba plantations were cultivated as dominant species in forest community areas, such as in $\mathrm{G}$ arut D istrict, West Java Province. Parungpanjang was selected to represent the common site condition of forest plantation industries that are generally established in podsolic soil associated with low $\mathrm{pH}$ and low soil nutrients.

Four-month-old seedlings were planted at the fields in February 2013 (planting hole size $40 \mathrm{x}$ $40 \mathrm{x} 40 \mathrm{~cm}$ ) administered with $3 \mathrm{~kg}$ manure per seedling as basic fertilizer. The spacing between planting hole was $3 \times 3 \mathrm{~m}$. The experiment was conducted in randomized complete block design (RCBD) with 5 replications of 4 -tree row plots (Fig. 2). Within two months after planting, $100 \mathrm{~g}$ of NPK fertilizer (15:15:15) was applied to each

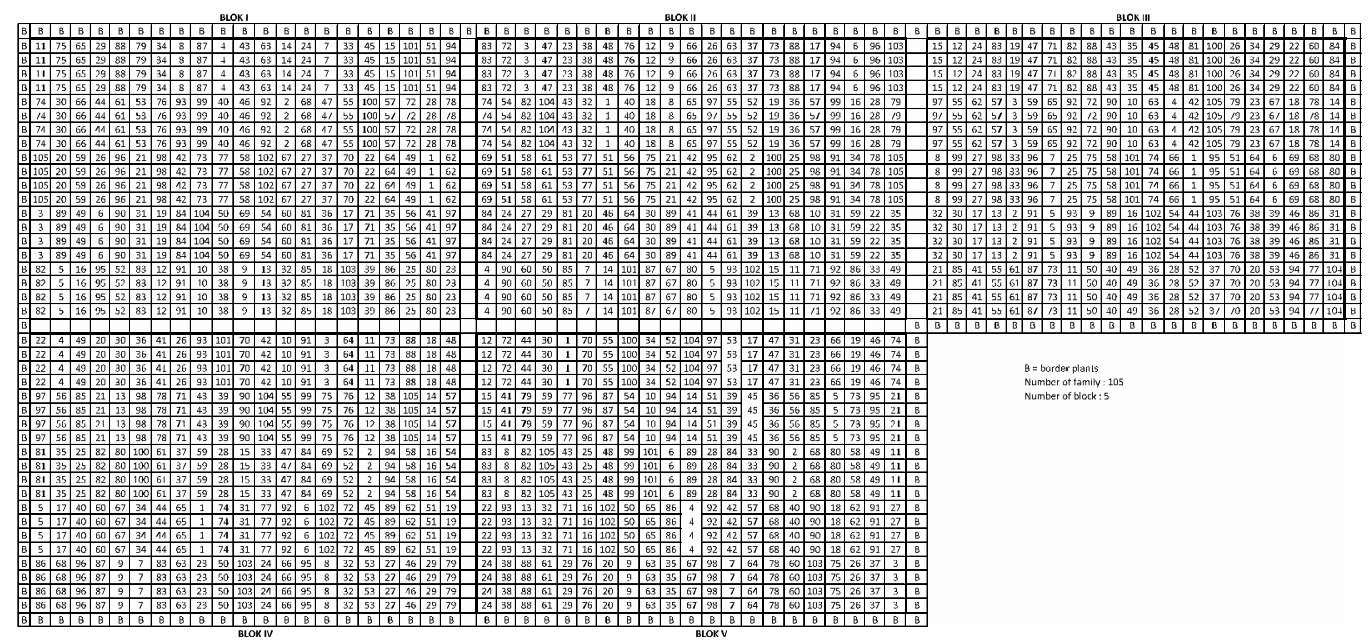

Figure 2 D esign of planting test of N. cadambaat Parungpanjang, Bogor and Limbangan, Garut 
plant. Weed competition was kept to a minimum by manual weeding. All trees in each plot constituted the measuring unit in all replications. The first assessment was carried out at the age of 6 months and subsequently after 12 months. In this paper, results of 16 months growth (4 months in nursery +12 months in field) planting have been described. The parameters assessed are height $(\mathrm{m})$, collar diameter $(\mathrm{cm})$ and survival percentage.

\section{Data Analysis}

The data were analyzed for each site, to determine the provenance and family effects using two-way analysis of variance (ANOVA). Before performing the analysis, data were examined for conformity to normal distribution and homogeneity of the variance assumptions. ANOVA for all parameters was conducted using the following statistical model (Falconer \& Mackay 1996; Sebbenn đal. 2003):

$$
\begin{aligned}
& Y i j k l=\mu+R i+P j+F(P) k(j)+R P i j+ \\
& R F(P) i k(j)+E l(i j k)
\end{aligned}
$$

An extra term (across site effect) was added to the model to investigate the significance of the difference of parameters across site.

Thus, the model used was:

Y ijkl $=\mu+S i+P j+F(P) k(j)+S P i j+S F(P) i k$

where :

$$
\text { (j) }+ \text { El(ijk) }
$$

Y ijkl = the measurement on the ${ }^{\text {th }}$ individual of the $\mathrm{k}^{\text {th }}$ family from the $\mathrm{j}^{\text {th }}$ provenance in the $\mathrm{i}^{\text {th }}$ replication

$\mu=$ the overall mean

$\mathrm{Ri}=$ the effect of $\mathrm{i}^{\text {th }}$ replication $(\mathrm{i}=1,2,3, . ., \mathrm{n})$

$\mathrm{Si}=$ the effect of $i^{\text {th }}$ site $(i=1,2)$

$P j=$ the effect of $j^{\text {th }}$ provenance $(j=1,2,3, \ldots, n)$

$F(P) k(j)=$ the effect of $k^{\text {th }}$ family in $j^{\text {th }}$ provenance

$$
(\mathrm{k}=1,2,3, \ldots, \mathrm{n})
$$

Rpij $=$ theinteraction effect between $\mathrm{i}^{\text {th }}$ replications and $j^{\text {th }}$ provenances

$R F(P) i k(j)=$ theinteraction between $i^{\text {th }}$ replications and $\mathrm{k}^{\text {th }}$ family within $\mathrm{j}$ th

$\mathrm{El}(\mathrm{ijk})=$ the residual . provenance

The SAS PROC GLM was used to obtain the coefficients of the expected mean squares for the calculation of heritability. The components of variance were calculated using VARCO MP PRO C from SA S statistical program (Cary 1999).
Heritability was estimated from the variance components as described in Falconer and Mackay (1996). Narrow sense individual ( $h^{2 i}$ ) and family heritability $\left(\mathrm{h}^{2} \mathrm{f}\right)$ for each parameter were estimated using equations:

$$
h^{2} i=\frac{\sigma^{2} A}{\sigma^{2} U}=\frac{4 \sigma^{2} F(P)}{\sigma^{2} U} ; \quad h^{2} f=\frac{\sigma^{2} F(P)}{\sigma^{2} f m}
$$

where:

$\sigma^{2} A=$ additive genetic variance

$4 \sigma^{2} F(P)=$ between-family-within-provenance variance component

$\sigma^{2} U=$ phenotypic variance calculated as $\sigma^{2} U=\sigma^{2} F^{-}$

$$
(P)+\sigma^{2} R F(P)+\sigma^{2} e,
$$

where:

$\sigma^{2} F(P)=$ variance due to interaction between replication and family-withinprovenance (experimental error)

$\sigma^{2} e=$ variance among individual trees within family (sampling error)

$\sigma^{2} \mathrm{fm}=$ family phenotypic variance, calculated as $\sigma^{2} f m=\sigma^{2} F(P)+\left(\mathrm{k}_{2} / \mathrm{k}_{3}\right) \sigma^{2} R F(P)+\left(1 / \mathrm{k}_{3}\right) \sigma^{2} e$,

where:

$\mathrm{k}_{2}$ and $\mathrm{k}_{3}=$ respectively, coefficients for $\sigma^{2} R F(P)$ $\sigma^{2} F(P)$ and in the expected mean squares.

Phenotypic ( $\mathrm{Rp}(\mathrm{xy})$ ) and genetic correlations (Rgxy)) were estimated from the component of variance and covariance (Falconer 1981) substituted into the standard equation for the product moment correlation coefficient:

$$
R_{P(x y)}=\frac{\operatorname{cov}_{P(x y)}}{\sqrt{\sigma^{2} P(x) \sigma^{2} P(y)}} ; R_{g(x y)}=\frac{\operatorname{cov}_{f(x y)}}{\sqrt{\sigma^{2} f(x) \sigma^{2} f(y)}}
$$

where:

$\sigma_{P(x)}^{2}$ and $\sigma^{2}{ }_{f(x)}=$ components of variance of phenotypic and genotypic products of $\mathrm{x}$ parameter

$\sigma_{P(y)}^{2}$ and $\sigma^{2} f(y)=$ components of variance of phenotypic and genotypic products of $\mathrm{y}$ parameter

$\operatorname{COV}_{P(x y)}$ and $\operatorname{COV}_{f(x y)}=$ components of covariance of phenotypic and genotypic products of $\mathrm{x}$ and $\mathrm{y}$ parameters, respectively.

Genetic gain $(\Delta)$ was calculated by Falconer's (1981) formula:

$\Delta \mathrm{G}=\mathrm{h}^{2} \mathrm{~S}=\mathrm{h}^{2} \mathrm{I} \sigma_{\mathrm{p}}$

where:

I = intensity of selection taken from Zobel and

Talbert (1984) with proportion selected 0.70,

0.50 and 0.30

$\sigma_{\mathrm{p}}=$ phenotypic standard deviation. 


\section{RESULTS AND DISCUSSION}

\section{Growth Rate and Genetic Variation}

Significant differences were observed among provenances and among families within provenances for all parameters at Limbangan and Parungpanjang, except for collar diameter of among provenances at Parungpanjang (Table 2). At the Limbangan, the KKP provenance attained a maximum height followed by GSJ, PKC, PGC and NKJ provenances. Maximum collar diameter was recorded in GSJ provenance followed by KKP, PGC, RPS and NKJ. Field survival was recorded maximum in KKP provenance, followed by KRS, PGS, RPS and GSJ. The KKP provenance had the highest height growth and presented approximately $44 \%$ faster than the slowest growth provenance. For root collar diameter, the GSJ provenance was higher and presented about $59 \%$ higher growth than the least growth provenance. The range of variation at family level of irrespective provenances was large in respect to height and root collar diameter (Table 3 ) as proven by values of coefficient of variation. Over all KKP, GSJ and PGC provenances were betterthan others.

The range of family variation (irrespective provenance) at Parungpanjang was high in all growth parameters. Maximum height was recorded in GSJ provenance, which was closely followed by APJ, NKJ, KKP and BHS provenances. Maximum root collar diameter was attained by BHS provenance, however, it was at par with PKC, PGC and APJ provenances. GSJ provenance had the highest growth for height and presented about 17\% higher growth than the least growth provenance. For root collar diameter, differences among provenances means were not statistically significant and the best provenance was only $10 \%$ larger than the least provenance. Ten provenances showed field survival more than $70 \%$, except APJ and BLB provenances. Based on the values of $\mathrm{CV}$ and range of the family means, a wide range of variability was observed in respect of growth parameters (Table 3).

The height and collar diameter growth of N. cadambawere better at Limbangan than those at Parungpanjang. The plant growth at Parungpanjang was affected by heavy growth of weeds causing suppression and competition for nutrition and growth space. The factor might have led to slow growth of the plant at the site. On the other hand, survival percentage was higher at Parungpanjang. Survival percentage at Limbangan was reduced by disturbance of domestic animal and irregular agricultural crops in several parts of the area covering the main plants in early growth of seedlings. In general, growth performance in both sites is better than the other progeny test of $\mathrm{N}$. cadambaconducted in Wonogiri, Central Java Province (Setyadi \& al. 2013).

D ifferences in height and root collar diameter growth were greater among families than among provenances. At Limbangan, the best growing family exceeded the least growing family by $243 \%$ and $234 \%$ for height and root collar diameter,

Table2 Mean square for height and collar diameter in provenance-progeny tests of N. cadamba at two sites in West Java Province, Indonesia

\begin{tabular}{|c|c|c|c|c|c|c|c|}
\hline \multirow{3}{*}{ Source of variation } & \multirow{3}{*}{$\begin{array}{l}\text { D egrees } \\
\text { of } \\
\text { freedom }\end{array}$} & \multicolumn{6}{|c|}{ Mean square } \\
\hline & & \multicolumn{3}{|c|}{ Limbangan, G arut } & \multicolumn{3}{|c|}{ Parungpanjang, Bogor } \\
\hline & & $\begin{array}{l}\text { Height } \\
(\mathrm{m})\end{array}$ & $\begin{array}{c}\text { Collar diameter } \\
(\mathrm{cm})\end{array}$ & $\begin{array}{c}\text { Survival } \\
(\%)\end{array}$ & $\begin{array}{l}\text { Height } \\
(\mathrm{m})\end{array}$ & $\begin{array}{l}\text { Collar diameter } \\
(\mathrm{cm})\end{array}$ & $\begin{array}{c}\text { Survival } \\
(\%)\end{array}$ \\
\hline Blocks & 4 & $61.281 * *$ & $221.693 * *$ & $9,310.667 \mathrm{~ns}$ & $8.604 * *$ & $35.499 * *$ & $25,694.552 * *$ \\
\hline Provenance & 11 & $3.858 * *$ & $16.933^{* *}$ & 3,949.994ns & $0.833^{*}$ & $1.6748 \mathrm{~ns}$ & $2,902.045 \mathrm{~ns}$ \\
\hline Fam (Prov) & 93 & $2.165 * *$ & $8.051 * *$ & $2,018.897 \mathrm{~ns}$ & $0.864 * *$ & $3.428 * *$ & 2,167.913ns \\
\hline Block*Prov & 44 & 1.859 ** & $6.208 *$ & $1,860.280 \mathrm{~ns}$ & $1.196 * *$ & $4.758 * *$ & 2,799.698ns \\
\hline Block*Fam(Prov) & 359 & $1.973 * *$ & $7.498 * *$ & 2,644.036ns & $1.053 * *$ & $3.897 * *$ & 2,841.399ns \\
\hline Error & 1,044 & 0.740 & 3.353 & $2,153.968$ & 0.413 & 1.681 & $1,862.556$ \\
\hline
\end{tabular}

Notes: ${ }^{* *}=$ significant at $p<0.01$

$*=$ significant at $p<0.05$

ns $=$ not significant 
Table3 Growth performance (mean \pm standard deviation) of various provenances in provenance-progeny tests of N. cadambaat two sites in West Java Province, Indonesia (numberin parentheses are ranks)

\begin{tabular}{|c|c|c|c|c|c|c|}
\hline \multirow[b]{2}{*}{ Provenance } & \multicolumn{3}{|c|}{ Limbangan, Garut } & \multicolumn{3}{|c|}{ Parungpanjang, Bogor } \\
\hline & $\begin{array}{l}\text { Height } \\
(\mathrm{m})\end{array}$ & $\begin{array}{c}\text { Collar } \\
\text { diameter }(\mathrm{cm})\end{array}$ & $\begin{array}{c}\text { Survival } \\
(\%)\end{array}$ & $\begin{array}{l}\text { Height } \\
(\mathrm{m})\end{array}$ & $\begin{array}{c}\text { Collar } \\
\text { diameter }(\mathrm{cm})\end{array}$ & $\begin{array}{c}\text { Survival } \\
(\%)\end{array}$ \\
\hline RPS & $2.34 \pm 1.20(8)$ & $4.78 \pm 2.77(4)$ & $62.5(4)$ & $1.97 \pm 0.58(12)$ & $4.06 \pm 1.59(7)$ & $77.5(2)$ \\
\hline KRS & $2.14 \pm 1.12(11)$ & $3.92 \pm 2.26(11)$ & $63.9(2)$ & $2.08 \pm 0.82(8)$ & $3.93 \pm 1.66(10)$ & $75.0(6)$ \\
\hline OKS & $2.46 \pm 1.48(6)$ & $4.45 \pm 2.53(8)$ & $58.6(8)$ & $2.04 \pm 0.78(11)$ & $3.94 \pm 1.54(9)$ & $70.9(9)$ \\
\hline GSJ & $2.67 \pm 1.47(2)$ & $5.35 \pm 2.75(1)$ & $61.9(5)$ & $2.31 \pm 0.79(1)$ & $4.11 \pm 1.26(5)$ & $71.9(8)$ \\
\hline NKJ & $2.47 \pm 1.34(5)$ & $4.68 \pm 2.59(5)$ & $50.7(11)$ & $2.26 \pm 0.99(3)$ & $4.09 \pm 1.73(6)$ & $70.7(10)$ \\
\hline APJ & $2.17 \pm 1.10(9)$ & $4.08 \pm 2.31(10)$ & $53.2(10)$ & $2.28 \pm 0.98(2)$ & $4.13 \pm 1.78(4)$ & $68.2(11)$ \\
\hline BLB & $2.17 \pm 1.16(10)$ & $4.27 \pm 2.41(9)$ & $58.8(7)$ & $2.12 \pm 0.78(6)$ & $3.78 \pm 1.55(12)$ & $57.5(12)$ \\
\hline KTB & $1.89 \pm 1.30(12)$ & $3.35 \pm 2.45$ (12) & $60.2(6)$ & $2.05 \pm 0.40(10)$ & $3.86 \pm 1.22(11)$ & $73.8(7)$ \\
\hline PGC & $2.57 \pm 1.30(4)$ & $4.87 \pm 2.61(3)$ & $63.7(3)$ & $2.06 \pm 0.81(9)$ & $4.14 \pm 1.74(3)$ & $76.4(3)$ \\
\hline $\mathrm{PKC}$ & $2.58 \pm 0.89(3)$ & $4.56 \pm 2.72(6)$ & $47.5(12)$ & $2.11 \pm 0.82(7)$ & $4.17 \pm 1.67(2)$ & $78.9(1)$ \\
\hline BHS & $2.42 \pm 0.75(7)$ & $4.49 \pm 2.07(7)$ & $53.8(9)$ & $2.21 \pm 0.92(5)$ & $4.19 \pm 1.78(1)$ & $76.3(4)$ \\
\hline KKP & $2.73 \pm 0.95$ (1) & $5.15 \pm 2.06(2)$ & $75.0(1)$ & $2.25 \pm 0.71(4)$ & $4.00 \pm 1.38(8)$ & $75.0(5)$ \\
\hline Family range & $1.40-4.81$ & $2.10-7.03$ & $35-90$ & $1.38-2.97$ & $2.50-5.56$ & $40-100$ \\
\hline Mean & 2.42 & 4.49 & 59.1 & 2.14 & 4.08 & 72.7 \\
\hline CV (\%) & 35.50 & 40.76 & & 30.06 & 31.76 & \\
\hline
\end{tabular}

Notes: RPS = Rimbopanti Nature Reserve-Sumatera, KRS = K ampar-Riau-Sumatera, OKS = O gan Komering Ilir-Sumatera, GSJ = G arut Selatan-Java, NKJ = Nusa K ambangan, APJ = Alas Purwo-Java, BLB = Batulicin-K alimantan, KTB =Kapuas-Kalimantan, PG C = Parangloe-Sulawesi, PKC = Pomalaa-Sulawesi, $\mathrm{BHS}=$ Batuhijau-Sumbawa, $\mathrm{KKP}=$ Kuala Kencana-Papua

Table $4 \mathrm{G}$ rowth performance (mean \pm standard deviation) of various provenances of $\mathrm{N}$. cadanmaacross different sites

\begin{tabular}{cccc}
\hline Provenance & Height $(\mathrm{m})$ & Collar diameter $(\mathrm{cm})$ & Survival $(\%)$ \\
\hline RPS & $2.15 \pm 0.94$ & $4.42 \pm 2.16$ & 70.0 \\
KRS & $2.11 \pm 0.97$ & $3.92 \pm 1.96$ & 69.5 \\
O KS & $2.25 \pm 1.19$ & $4.19 \pm 2.10$ & 64.8 \\
GSJ & $2.50 \pm 1.22$ & $4.77 \pm 2.27$ & 66.9 \\
NKJ & $2.35 \pm 1.16$ & $4.35 \pm 2.16$ & 60.7 \\
APJ & $2.23 \pm 1.04$ & $4.11 \pm 2.04$ & 60.7 \\
BLB & $1.97 \pm 0.77$ & $3.63 \pm 1.82$ & 58.2 \\
KTB & $2.15 \pm 0.71$ & $4.06 \pm 2.19$ & 67.0 \\
PGC & $2.30 \pm 1.10$ & $4.49 \pm 2.23$ & 70.1 \\
PKC & $2.33 \pm 1.10$ & $4.36 \pm 2.08$ & 63.2 \\
BHS & $2.31 \pm 1.05$ & $4.33 \pm 2.10$ & 61.9 \\
KKP & $2.50 \pm 0.86$ & $4.59 \pm 1.83$ & 61.3 \\
\hline F test: Provenance & $2.80 *$ & $3.57 * *$ & $1.43 \mathrm{~ns}$ \\
Provenance*Site & $2.49 \mathrm{~ns}$ & $2.14 \mathrm{~ns}$ & $0.70 \mathrm{~ns}$ \\
Family*Site & $1.55 \mathrm{~ns}$ & $1.41 \mathrm{~ns}$ & $0.84 \mathrm{~ns}$ \\
\hline
\end{tabular}

Notes: $* *=$ significant at $p<0.01$

$*=$ significant at $\mathrm{p}<0.05$

$\mathrm{ns}=$ not significant

respectively. At Parungpanjang, the best family exceeded the least family by $57 \%$ and $122 \%$ for height and root collar diameter, respectively (data are not shown). These results showed the potential of provenance-progeny test of $\mathrm{N}$. cadamba for selection. Analysis of variance across the sites revealed no significant provenance against site interaction and family within provenance against 
site interaction for all parameters (Table 4). In across site, a significant difference was revealed by provenances for height and diameter parameters. Among different provenances, the performance of the GSJ and KKP provenances was found significantly superior than the others. The component of variance attributed to variation among provenances ranged from $0.5 \%$ for height at Parungpanjang to $1.7 \%$ for root collar diameter at Limbangan. On the other hand, component of variance attributed to variation among families within provenances were lower than component of variance among provenance, ranged from 0.4 to $0.6 \%$ at both sites (Table 5). The higher values toward variation among provenance in relation to families within provenances suggested that provenances are isolated or gen flow is insufficient to overlap the effect of selection and/ or genetic drift. Larger genetic variation among provenances than genetic variation among families within provenances were also observed in provenanceprogeny test by Z heng \&al. (1994) for Pinuscaribact in China, Bali-Uckas \&al. (1999) for A crplatanides in Sweden, Sebbenn \& al. (2003) for Araurania angustifdia in Brazil, Adinugraha \& al. (2013) for Tetona gandis in Gunung Kidul, and Setiadi and
Fauzi (2015) for Araucaria anninghamii in Bondowoso, Indonesia. On the other hand, study based on AFLP loci using 4 populations of $\mathrm{N}$. cadamba showed that variation among population (27\%) was much lower than variation within population (73\%) (Sudrajat \&al. 2015). Different trend was caused by different number and distribution of N. cadamba population.

\section{Genetic Parameters}

Phenotypic and genetic correlations between height and root collar diameter parameters at Parungpanjang were higher than those at Limbangan (Table 6). This indicated that the possibility of selection in one parameter at Parungpanjang is more efficient than those at Limbangan. Phenotypic correlations were higher than genetic correlations among height and root collar diameter parameters (Table 5). High phenotypic correlation provided more support for combining these surveyed parameters as early selecting criteria.

Narrow sense individual $\left(h^{2} \mathrm{i}\right)$ and within families (hff) heritability at Limbangan were poor (ranged from 0.031 to 0.055), while the

Table 5 Components of variance and relative contribution (number in parentheses) of replications $\left(\sigma_{\mathrm{R}}^{2}\right)$, provenances $\left(\sigma_{\mathrm{p}}^{2}\right)$, interaction between replications and provenances $\left(\sigma_{\mathrm{RP}}^{2}\right)$, families within provenances $\left(\sigma_{\mathrm{FP}}^{2}\right)$, interaction between replications and families $\left(\sigma_{\mathrm{RF}(\mathrm{P})}^{2}\right)$ and individual within families $\left(\sigma_{\mathrm{e}}^{2}\right)$ of provenance-progeny tests at two sites in West JavaProvince, Indonesia

\begin{tabular}{|c|c|c|c|c|}
\hline \multirow{2}{*}{$\begin{array}{l}\text { Components of } \\
\text { variance }\end{array}$} & \multicolumn{2}{|c|}{ Limbangan, Garut } & \multicolumn{2}{|c|}{ Parungpanjang, Bogor } \\
\hline & $\begin{array}{l}\text { Height } \\
\text { (m) }\end{array}$ & Collar diameter $(\mathrm{cm})$ & $\begin{array}{l}\text { Height } \\
\text { (m) }\end{array}$ & Collar diameter $(\mathrm{cm})$ \\
\hline$\sigma^{2} R$ & $0.49330(28.0 \%)$ & $1.54578(22.9 \%)$ & $0.06746(9.1 \%)$ & $0.27601(9.5 \%)$ \\
\hline$\sigma^{2} \mathrm{P}$ & $0.02681(1.5 \%)$ & $0.11501(1.7 \%)$ & $0.00377(0.5 \%)$ & $0.04134(1.4 \%)$ \\
\hline$\sigma_{\mathrm{RP}}^{2}$ & $0.00465(0.3 \%)$ & $0.04640(0.7 \%)$ & $0.01546(2.1 \%)$ & $0.07356(2.5 \%)$ \\
\hline$\sigma^{2} \mathrm{F(P)}$ & $0.01045(0.6 \%)$ & $0.03875(0.6 \%)$ & $0.00359(0.5 \%)$ & $0.01216(0.4 \%)$ \\
\hline$\sigma^{2} \operatorname{RF}(\mathrm{P})$ & $0.48827(27.7 \%)$ & $1.64063(24.3 \%)$ & $0.23901(32.2 \%)$ & $0.82821(28.4 \%)$ \\
\hline$\sigma^{2} \mathrm{e}$ & $0.74002(42.0 \%)$ & $3.35359(49.8 \%)$ & $0.41369(55.7 \%)$ & $1.68163(57.7 \%)$ \\
\hline
\end{tabular}

Table6 Genetic (upper diagonal) and phenotype (lower diagonal) correlation coefficients among traits in provenanceprogeny tests of N. cadanbaat two sitesin WestJava Province, Indonesia

\begin{tabular}{|c|c|c|c|c|}
\hline & \multicolumn{2}{|c|}{ Limbangan, G arut } & \multicolumn{2}{|c|}{ Parungpanjang, Bogor } \\
\hline & Height & Collar diameter & Height & Collar diameter \\
\hline Height & & 0.29 & & 0.56 \\
\hline Collar diameter & $0.799 * *$ & & $0.885^{* *}$ & \\
\hline
\end{tabular}

Note: $^{* *}=$ significant at $p<0.01$ 
Table 7 Estimated heritabilities in provenance-progeny tests of N. cadamba at two sitesin WestJavaProvince, Indonesia

\begin{tabular}{lcccccc}
\hline & \multicolumn{2}{c}{ Limbangan, Garut } & & \multicolumn{2}{c}{ Parungpanjang, Bogor } \\
\cline { 2 - 3 } \cline { 5 - 6 } & Height & Collar diameter & & Height & Collar diameter \\
$\begin{array}{l}\text { Heritability at individual plant } \\
\text { level }-h^{2} i\end{array}$ & 0.034 & 0.031 & & 0.093 & 0.114 \\
Family heritability $-h^{2} f$ & 0.055 & 0.054 & & 0.150 & 0.178 \\
\hline
\end{tabular}

Notes: Category of heritability values according to Cotterill and D ean (1990):

heritability of $<0.1=$ poor

heritability of $0.1-0.3=$ moderate

heritability of $>0.3=$ high

Table 8 Estimates of genetic gain for height and diameter by within family of in provenance-progeny tests of N. cadamba

\begin{tabular}{ccccc}
\hline \multirow{2}{*}{ Proportion selected } & \multicolumn{2}{c}{ Garut } & \multicolumn{2}{c}{ Parungpanjang } \\
\cline { 2 - 5 } & Height & Diameter & Height & Diameter \\
\hline 0.30 & 0.13 & 0.18 & 0.31 & 0.16 \\
0.50 & 0.05 & 0.09 & 0.09 & 0.07 \\
0.70 & 0.03 & 0.05 & 0.05 & 0.04 \\
\hline
\end{tabular}

heritabilities at Parungpanjang site were moderate and ranged from 0.093 to 0.178 (Table 7). Values of heritability changed with sites with the same set of genotypes. Lower value of heritability of the trial in Limbangan could be due to high incidence of domestic animal and irregular agricultural crops covering several parts of area causing high environmental difference. Setyadi $\notin$ al. (2013) studied 75 half-sib N. adanba families explored from Java Island and found higher family heritability of approximately 0.32 for height and 0.38 for stem diameter at breast height. Poor values of heritability in this study could be due to plant age that was still young, indicating the genetic control of the parameters was still weak. For example at Parungpanjang, family heritability at 6 months old plant ( 0.093 for height and 0.066 for root collar diameter) was lower than family heritability at 12 months old plant ( 0.150 for height and 0.178 for root collar diameter), indicating heritability was not yet stable. Trend of increasing heritability with age was also reported in the studies of Eucalyptus gandis $(\mathrm{O}$ sario $\& \mathrm{al}$. 2001; G apare $\notin a$ al. 2003), Pinusbanksiana(Weng \& al. 2006) and E. urcphyla (Kien \& al. 2009). The increased heritability with age for growth parameters could also be resulted from competitive effects occurred in later age in the stand (Kien \&al. 2009). According to Zobel and Talbert (1984), the heritability values often change with age when the environment changes and when the genetic control of the characteristic changes as the trees reach mature age. Therefore, activities to improve site environment conditions will be very important to optimize growth and to reach stable heritability.

Heritability estimated should be interpreted carefully because of unequal number of families per provenances presented in the trials. In a multiprovenance-progeny test, the family variance is averaged across different provenances, with more information provided by the better-represented provenances (Kien $\notin a l .2009$ ). In all parameters at both sites, family heritability was found to be higher than individual heritability. Some studies in other species also revealed similar trend, such as in Araucaria angustifdiain Brazil (Sebbenn eal. 2003) and Pinusbntia in Turkey (Gulcu \& Celik 2009). This result indicated that higher genetic gain can beachieved with family selection.

Estimation of genetic gain is determined by heritability value, selection intensity and phenotypic standard deviation. In this research, simulation to predict the genetic gain used proportional selected family of $30 \%, 50 \%$ and $70 \%$ and the corresponding selection intensity were 1.15, 0.79 and 0.49 (Zobel \& Talbert 1984). The higher value of genetic gain estimation for height and collar diameter by proportional selected family of $30 \%$ was 0.13 and 0.18 for Limbangan and 0.31 and 0.16 for Parungpanjang (Table 8). Predictions of genetic gain from family 
selection simulation revealed that height parameter showed higher values than collar diameter parameters. It was also revealed that genetic gain of height parameters at Parungpanjang was higher than genetic gain at Limbangan. Johnson \&al. (1955) and Seghal eal. (1995) pointed out that heritability estimates along with genetic gain is more useful than heritability alone, because the heritability estimates indicated only the effectiveness of selection on genotype based on phenotypic performance, but fails to indicate the genetic progress. High heritability and genetic gain indicated the additive gen action on these parameters for their expression.

\section{CONCLUSIONS}

Levels of genetic variation in N. cadanba were found to be higher for all parameters among provenances than within provenances indicating possibility to use well performing provenances as seed sources for reforestation and regeneration practices. Estimated family heritability was higher than narrow sense individual heritability, indicating the possibility of greater gains with selection among families rather than mass selection. However, heritability was low to moderate and not yet stable for all parameters at both sites, indicating that possibility of genetic gains with selection is limited and selection should be done until the heritability reached relatively high and stable values. A combination of family and within family selection would be effective in improving growth of this species. Improving growth environment conditions with controlling the domestic animal and weed intensively should be applied immediately and continuously to optimize the plant growth, stabilize heritability and to optimize genetic gain.

\section{ACKNOWLEDGEMENTS}

The authors wish to acknowledge SEAMEOBIOTROP, PT. Arutmin Indonesia (Batu Licin, South Kalimantan), PT. Dasa Intiga (Kapuas, Central Kalimantan), PT. Newmont Indonesia (Batu Hijau, Sumbawa) for providing accommodations during genetic material exploration. The authors were grateful to the authorities of Forest Tree Seed Technology Research Institute, Bogor, for financing the establishment of provenance-progeny trials at Parungpanjang, Bogor and Limbangan, G arut.

\section{REFERENCES}

Acharyya S, Rathore DS, Kumar HKS, Panda N. 2011. Screening of Anthoephalus cadamba (Roxb.) Miq. root for antimicrobial and anthelmintic activities. Int.J Res Pharmaceut Biomed Sci 2(1):297-300.

Adinugraha HA, Pudjiono S, Mahfudz. 2013. G rowth variation and genetic parameter of progeny test of teak at 5 years old in Gunung Kidul, Yogyakarta. Jurnal Pemuliaan Tanaman Hutan 7(3):167-78.

Bali-Uckas V, Ekberg I, Eriksson G, Norell L. 1999. G enetic variation among and within provenances of four Swedish hardwood species assessed in a nursery trial. Silvae G enetica 48(1):17-25.

Borralho NMG. 2001. The purpose of breeding is breeding for a purpose. In: Developing the Eucalypt of the Future. Proceedings of the IUFRO International Symposium.

Cary NC. 1999. SAS: SAS Proedures GuideVerion8. USA: SASInstituteInc.

Cotterill PP, D ean CA. 1990. Successful tree breeding with index selection. Australia: CSIRO Division of Forestry and Forest Product.

Falconer DS. 1981. Introdution to Quantitative Gentic, $2^{\text {mb }}$ Edition NewYork: Longman Inc.

Falconer D S, Mackay TFC. 1996. Introduction to Quantitative Gentics $^{\text {th }}$ Edition Essex: Addison Wesley Longman Ltd.

Finkeldey F. 2005. Conservation and sustainable utilization of plant genetic resources in South East Asia. ASEAN-EU University Network Programme.

Gapare WJ, Gwaze DP, Musokonyi C. 2003. Genetic parameter estimated for growth and stem straightness in a breeding seedling orchard of Euralyptusgandis J Trop For Sci 15:613-25.

Gulcu S, Celik S. 2009. G enetic variation in PinusbutiaTen. seed stands and seed orchards for growth, stem form and crown characteristics. African J Biotech 8(18):4387-94.

Hamrick JL, G odt MJW. 1989. Allozyme diversity in plant species. In: Brown AHD, Clegg MT, Kahier AL, Weir BS, editor. Plant PopulationGentics Breeding and GenticResarces Massachusetts: Sinauer Associates. p 43-63.

Hashimoto K, Kurinobu S, Suhendi H. 1996. Establishment of seed sources of tropical tree species in Indonesia. In: Dieters MJ, Matheson AC, Nikles DG, Harwood CE, Walker SM, editor. 
Tree improvement for sustainable tropical forestry. Proceedings of QFRI-IUFRO Conference. pp 370-1.

Johnson HW, Robinson HF, Comstock RF. 1955. Estimates of genetic and environmental variability in Soyabean. Agronomy Journal 47:14-318.

Kallio MH, Krisnawati H, Rohadi D, Kanninen M. 2011. Mahogany and kadam planting farmers in South Kalimantan: the link between silvicultural activity and stand quality. Small-scale Forestry 10:115-32.

Kien ND, Jansson G, Harwood C, Thinh HH. 2009. G enetic control of growth and form in Eucalyptusurophylain Northern Vietnam.J Trop For Sci 21(1):50-65.

Krisnawati H, Kallio M, Kanninen M. 2011. Anthocephelus cadamba Miq.: ecology, silviculture and productivity. Indonesia: Center for International Forestry Research.

Lamprecht H. 1989. Silviculture in the tropics; Tropical forest ecosystems and their tree species- Possibilities and methods for their long-term utilization. Eschbor (DE): Deutsche Gesellschaft fur TechnischeZusammenarbeit(GTZ).

Mishra RP, Siddique L. 2011. Antibacterial properties of Anthocephalus cadamba fruits. A sian J Plant Sci Res 1(2):1-7.

Nebgen RJ, Lowe WJ. 1982. Inheritance of growth, branch angle, and specific gravity in three American sycamorepopulations. Silvae G enetica31(2-3):86-9.

O sario LF, White TL, Huber DA. 2001. Age trends of heritability and genotype by environmentinteraction for growth traits and wood density from clonal traits of EucalyptusgandisHill ex Maiden. Silvae G enetica 50:30-7.

Rawat K, Bakshi M. 2011. Provenance variation in cone, seed and seedling characteristics in natural populations of Pinus vallidiana A.B. Jacks (Blue Pine) in India. Annals of Forest Research 54(1):3955.

Sebbenn AM, Pontinha AAS, Kageyama PY. 2003. G enetic variation in provenance-progeny test of Araucana angusifdia(Bert.) O. Ktze. in Sao Paulo, Brazil. Silvae Genetica 52:5-6.
Seghal RN, Chauhan SK, D hall SP. 1995. Half sib progeny evaluation in chir pine. Sil G en 44:61-6.

Setiadi D, Fauzi MA. 2015. Genetic parameters on combination provenance-progeny test of Araurana aminghamii origin from Manokwari (Papua) in Bondowoso, East Java. Jurnal Penelitian Kehutanan Wallacea 4(2):129-36.

Setyadi T, Nirsatmanto A, Sunarti S. 2013. G enetic variation on early growth of jabon (Antocephalus spp.) observed in first generation seedling seed orchard. In: International Conference of Indonesia Forestry Researchers. Proceedings: 27-28 August 2013, Forestry Research and Development Agency of Indonesia. Bogor.

Soerianegara I, Lemmens RHMJ. 1993. Plant Resarces of SathEast Asia 5(1): Timber Tres Major Commedal Timbes Wageningen: Pudoc Scientific Publishers.

Soeseno OH. 1988. Genetic variation and improvement of Pinus mokusi Jungh et de Vriese. Dissatation Yogyakarta (ID ): G ajah Mada University.

Sudrajat DJ, Siregar IZ, Siregar UJ, K humaida N, Mansur I. 2015. Genetic diversity of white jabon (Anthocephalus cadanba Miq.) based on AFLP markers. Asia Pasific Journal of Moleculer Biology and Biotechnology 2(3):224-231.

Sudrajat DJ. 2016. Genetic variation of fruit, seed, and seedling characteristics among 11 populations of white jabon in Indonesia. Forest Science and Technology 12(1):9-15.

Weng YH, Tosh KJ, Park YS, Fullarton MS. 2006. Agerelated trends in genetic parameters forjack pine and their implications for early selection. Silvae G enetica 56(5):242-52.

Xu XY, Yang XH, Li SZ, Song QS. 2011. Two new triterpenoid glycosides from the leaves of Anthoephalusdinensis J A sian Nat Prod Res 1-6.

ZhengYO, Ennos R, Wang HR. 1994. Provenance variation and genetic parameters in a trial of Pinus caribaea Morrelet var. bahamensis and Golf. For Genet 1(3):165-74.

Zobel B, Talbert JT. 1984. Applied Forest Tree Improvement. New York: John Willey and Sons. p 504 . 